\title{
The base of the Curionii Zone (Ladinian, Triassic) in Felsőörs (Hungary): improved correlation with the Global Stratotype Section
}

\author{
Attila Vörös \\ Research Group for Paleontology \\ Hungarian Academy of Sciences \\ Hungarian Natural History Museum, Budapest
}

Tamás Budai

Geological Institute of Hungary, Budapest

Imre Szabó

retired

Recent excavation and sampling in the upper part of the Felsőors section (Balaton Highland, Hungary) yielded important ammonoid findings, identified as belonging to the genera Nevadites, Chieseiceras, Eoprotrachyceras and Falsanolcites. Several specimens of Chieseiceras chiesense were found in a dm-thick clay layer with limestone nodules, regarded as the equivalent of the "Chiesense Groove" of the Bagolino and other sections in the Giudicarie area (North Italy). The immediately overlying limestone bed yielded Eoprotrachyceras cf. curionii and Falsanolcites cf. rieberi. Together these reliably prove the base of the Curionii Zone, corresponding to the base of the Ladinian Stage, the GSSP of which was recently established at Bagolino. The new data further improved the excellent correlation between the ammonoid records of the Felsőörs section and the Global Stratotype Section at Bagolino. Felsöörs may be considered the most important reference section for the Anisian to Ladinian boundary interval.

Key words: biostratigraphy, ammonoids, Middle Triassic, Felsőörs, Hungary

\section{Introduction}

The Middle Triassic section at Felsőörs (Balaton Highland) is one of the most famous geologic localities of Hungary. The fossiliferous strata at the hillside (also known as Forrás-hegy or Malom-völgy), highlighted by the classical occurrence of the ammonite Reitziites reitzi, were a candidate for the "golden spike" of the Ladinian GSSP.

In the course of his geologic mapping in 1870, J. Böckh recognized, on the slope of the Forrás-hegy, the "Kalkstein mit Cer. Reitzi", a very siliceous, yellow or gray

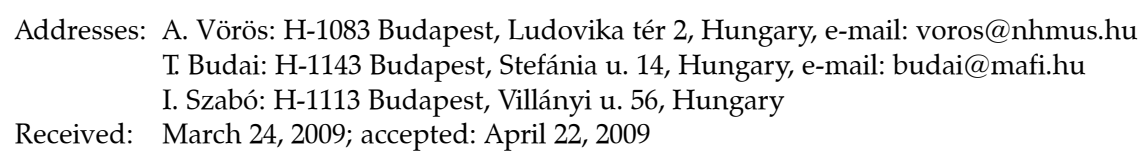


limestone with greenish marly coatings and many new ammonite species (Böckh 1873 , pp. 65, 66), which he placed in the Upper Triassic at that time. In order to reveal the bedding and lithology of the poorly-exposed tuffaceous sequence, following Böckh's instructions systematic excavations were made by Roth (1871) and Stürzenbaum (1875), who collected and described a few new ammonoid species from the locality. A more detailed description of the ammonoids from the "cherty, Cer. Reitzi-bearing limestones" was given by Böckh (1872, 1873 and 1874) who consistently indicated the locality as "Királykút-Thal" (Királykút Valley), the downstream continuation of Malom Valley (Malom-völgy), SW of Felsőörs. Even more ammonoids collected from Felsőorrs were described in the magnificent and comprehensive monograph by Mojsisovics (1882), where the fauna of the "gelbe, kieselreiche Kalk von Felsö-Örs" was introduced as the type fauna of the "Zone des Trachyceras Reitzi". He placed this zone at the base of his "Norische Stufe" which was later renamed by Bittner (1892) as Ladinian.

Although the Felsőorrs section has been a famous site for Hungarian geologists and students, and occasionally some nice ammonites have been collected (e. g. by Z. Schréter and I. Szabó), no updated revisions have been published for a century. The papers by Szabó and Ravasz (1970), Szabó et al. (1980), Cros and Szabó (1984), Haas et al. (1986), Kovács (1994) and Kovács et al. $(1990,1994)$, based on detailed new samplings, provided valuable data on the sedimentology (including the volcanoclastics) and the micropaleontology of the section, but in ammonoid biostratigraphy they did not go much beyond the repetition of the classical knowledge.

In the last decades, the international quest for the Ladinian GSSP invoked the modern re-evaluation of the Felsőörs section, because it was obvious that this ammonoid-rich sequence of beds straddles the stratigraphic interval passing from the Anisian to the Ladinian. Therefore, we organized several campaigns (in 1989, 1992, 1995, with the participation of T. Budai, L. Bujtor, L. Dosztály, A. Dulai, M. Gasparik, J. Pálfy, I. Szabó, P. Vincze and A. Vörös) in order to sample the section bed-by-bed for ammonoids. The preliminary results on the newly collected ammonoid fauna and a re-definition of the Reitzi Zone were published by Vörös (1993); later Vörös et al. (1996) gave a more detailed and revised description of the section. Simultaneously the conodont biostratigraphy was excellently elaborated and published by Kovács (1994). The summarized magnetostratigraphic results and the integrated stratigraphy of the Felsöörs section were described by Márton et al. (1997); the sequence stratigraphic relationships were evaluated by Budai and Haas (1997). The broader stratigraphic and facies context of the Felsőörs section was highlighted by Budai et al. (2001). Several coarse-grained tuffite layers from Felsőörs were sampled for zircons and the resulting $\mathrm{U}-\mathrm{Pb}$ geochronometry was published by Pálfy et al. (2003). The geologic description of the section (as exposed up to that time) and the applied stratigraphic schemes can be seen in detail in the above publications. 
Due to the historical priority and the high-level, up-to-date knowledge of its complex stratigraphy, the Felsöörs section seemed to fulfill the stringent requirements of a GSSP set by the International Commission on Stratigraphy (ICS). At the end of long debates in working group meetings (Anisian-Ladinian task force) in the Subcommission on Triassic Stratigraphy (STS), three candidate positions for the base of Ladinian were outlined and suggested: (1) at the appearance (FAD) of Reitziites (i.e. Reitzi Subzone), advocated by Vörös et al. (2003), (2) at the FAD of Aplococeras (i.e. Avisianum Subzone), favored by Mietto et al. (2003a) and (3) at the FAD of Eoprotrachyceras (i.e. Curionii Zone) proposed by Brack et al. (2003). The first two candidates were perfectly recorded in the Felsőörs section, whereas the third, i.e. the Curionii Zone was not proved here at that time. Partly for this pragmatic reason, but mainly in the firm belief that the application of the FAD of Reitziites as the base of Ladinian has the best potential in correlation and maintains stability in geologic practice, we submitted to the STS a proposal for the Reitzi Subzone at Felsőors as the Ladinian GSSP (Vörös et al. 2003). Subsequently, in repeated voting in the Anisian-Ladinian task force during 2003-2004, the Reitzi and the Curionii proposals were in close contest, but finally the latter obtained the majority of the votes. Consequently, the GSSP of the Ladinian Stage was defined at the base of the Curionii Zone in the Bagolino section (Southern Alps, Northern Italy); this was approved by the ICS and ratified by the IUGS Executive Committee in 2005 .

The base of the Curionii Zone (i. e. the base of the Ladinian) was supposed to be present in the higher, previously unexcavated part of the Felsöörs section. In fact, P. Brack (pers. comm.) made an educated guess on the expected position of this level in Felsőörs, by extrapolation of the thickness rates at Bagolino. In 2004, we (I. Szabó, A. Vörös, T. Budai) carried out complementary excavation and sampling in the upward continuation of the Felsöors section with successful results.

\section{The new results}

The geologic setting of the Felsöörs section and its deeper, more than sixty meter-thick part, was described and illustrated in many previous papers (e. g. Szabó et al. 1980; Haas et al. 1986; Vörös et al. 1996; Vörös 1998; Budai et al. 1999; Pálfy et al. 2003; Vörös et al. 2003); therefore, in the present paper, we show and discuss only the recently excavated part (Figs $1-3$ ).

The predominantly tuffaceous, middle part of the Felsöörs section (Vászoly Formation, Beds 100 to 111 ) is distinctly terminated by a $40 \mathrm{~cm}$-thick massive, cherty limestone bank (Bed 112). In 1995, L. Dosztály found a fragment of a Chieseiceras in the upper part of the overlying tuffaceous clayey beds. It was believed to represent the species Ch. chiesense (Vörös 1998, pl. VIII, fig. 4), thus indicating the "Chiesense horizon", immediately underlying the Curionii Zone as it was known in the Giudicarie area (Brack and Rieber 1986, 1993). Later, H. 
NW

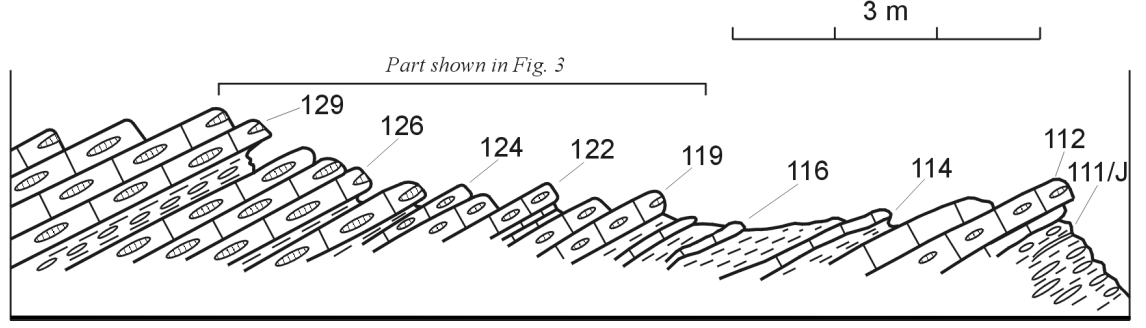

Fig. 1

Geologic sketch of the upper part of the Felsöörs section, as excavated in 2004 with the numbering of critical beds. For legend see Fig. 3

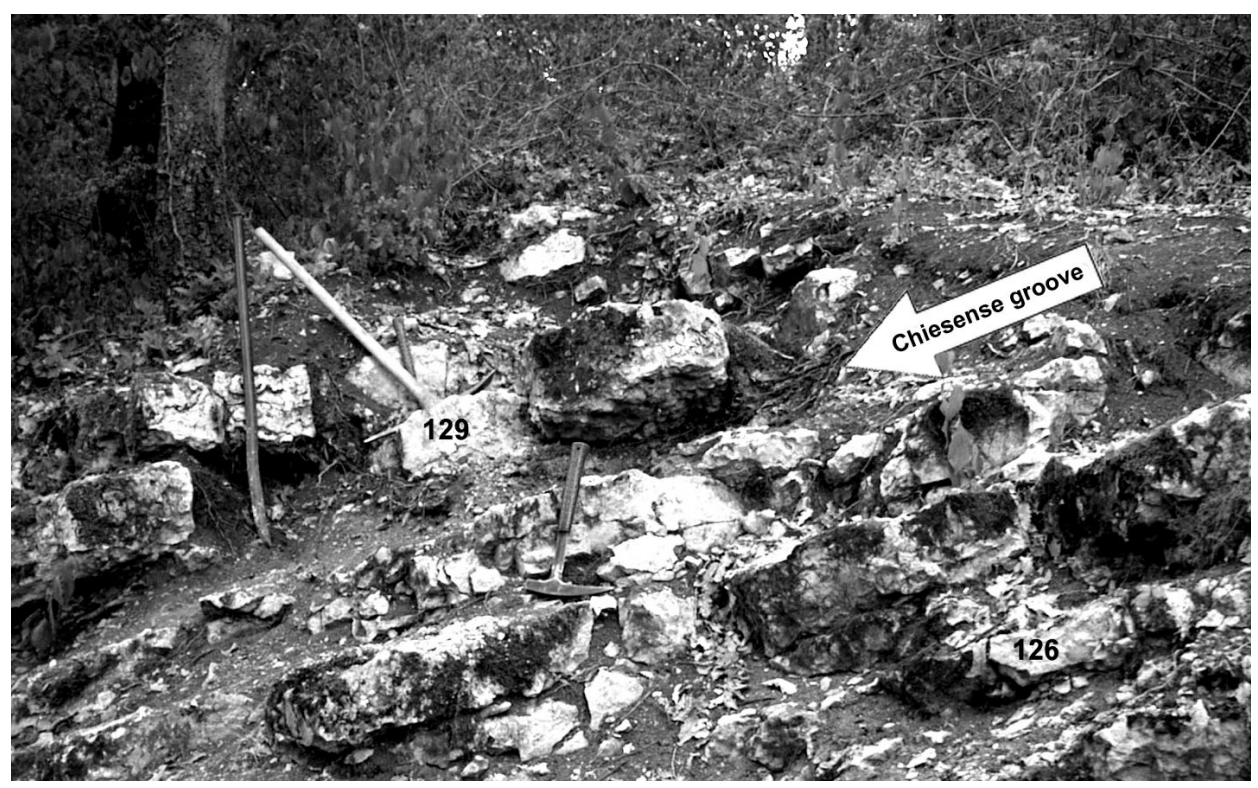

Fig. 2

The outcrop of the uppermost part of the Felsőors section, as excavated in 2004, showing the "Chiesense groove"

Rieber (pers. comm.) pointed out that the mentioned specimen does not belong to chiesense but another, older species of Chieseiceras.

From Bed 119 upward the dominant lithology is cherty limestone forming 10 to $40 \mathrm{~cm}$-thick beds with rare clayey interlayers of variable thickness (Buchenstein Formation, Figs 1-3). The limestone beds, gently $\left(20-30^{\circ}\right)$ dipping to the NW, contain reddish or light-gray chert nodules, or even large lenses; the bedding surfaces are uneven or nodular. The excavated and sampled interval (Beds 119-130) proved to be extremely poor in fossils. Megafossils were not 
Fig. 3

Stratigraphic column of the uppermost part of the Felsőörs section with the occurrences and specimen numbers of the identified ammonite taxa. Legend: 1. limestone, cherty limestone, 2. tuffaceous clay, with limestone lenses, 3 . tuffites, with limestone lenses or nodules
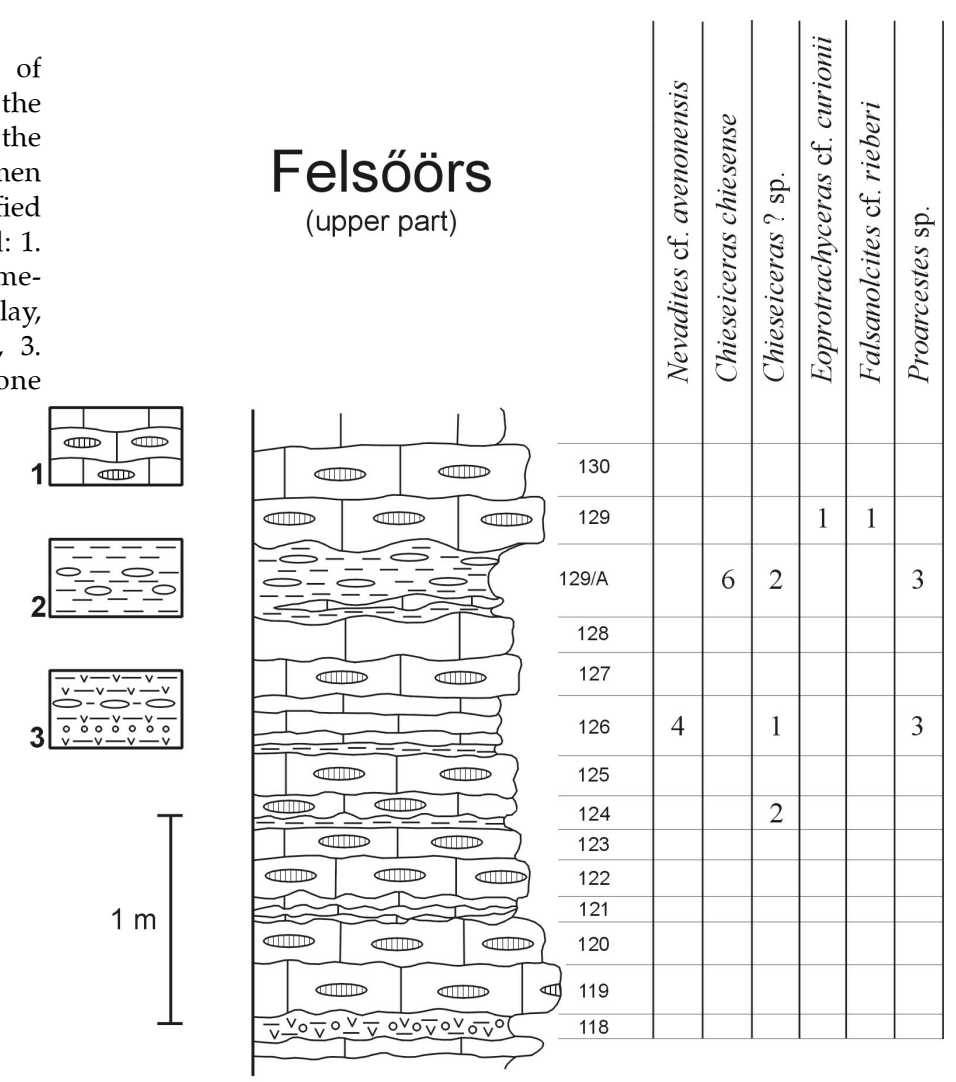

encountered within the cherty limestone beds; the rare ammonoid specimens were found on the lower surfaces of the beds, or as subsolution fragments in the clayey interbeds. As for the labeling of the beds, we were fortunate to find some of the previous numberings by S. Kovács (written with red paint) marking the points of conodont sampling, corresponding to those used in the paper of Kovács (1994). Thus, our bed number 125 corresponds to "5/86" of Kovács (1994); our Bed 129 is the equivalent to "9/86" of Kovács (1994), and so forth.

Most beds did not yield any fossils. However, we found a Chieseiceras? sp. specimen and a few poorly preserved, fragmentary exemplars of Nevadites avenonensis Brack and Rieber (1993) in the clayey interbed underlying limestone bed 126 (Plate I, Figs 1, 3, 4). The most fortunate sampling point was the thick clay bed with limestone nodules just below the massive, $30 \mathrm{~cm}$-thick limestone Bed 129. This $40 \mathrm{~cm}$-thick clayey bed (labeled as 129/A) yielded a surprisingly high number (8) of Chieseiceras chiesense (Mojsisovics, 1882) specimens in a moderate state of preservation (Plate I, Fig. 2, Plate II, Figs 2, 3). Another two pieces of ammonoids were freed from the lower bedding surface of Bed 129; these very poorly preserved specimens were tentatively identified as Eoprotrachyceras cf. 

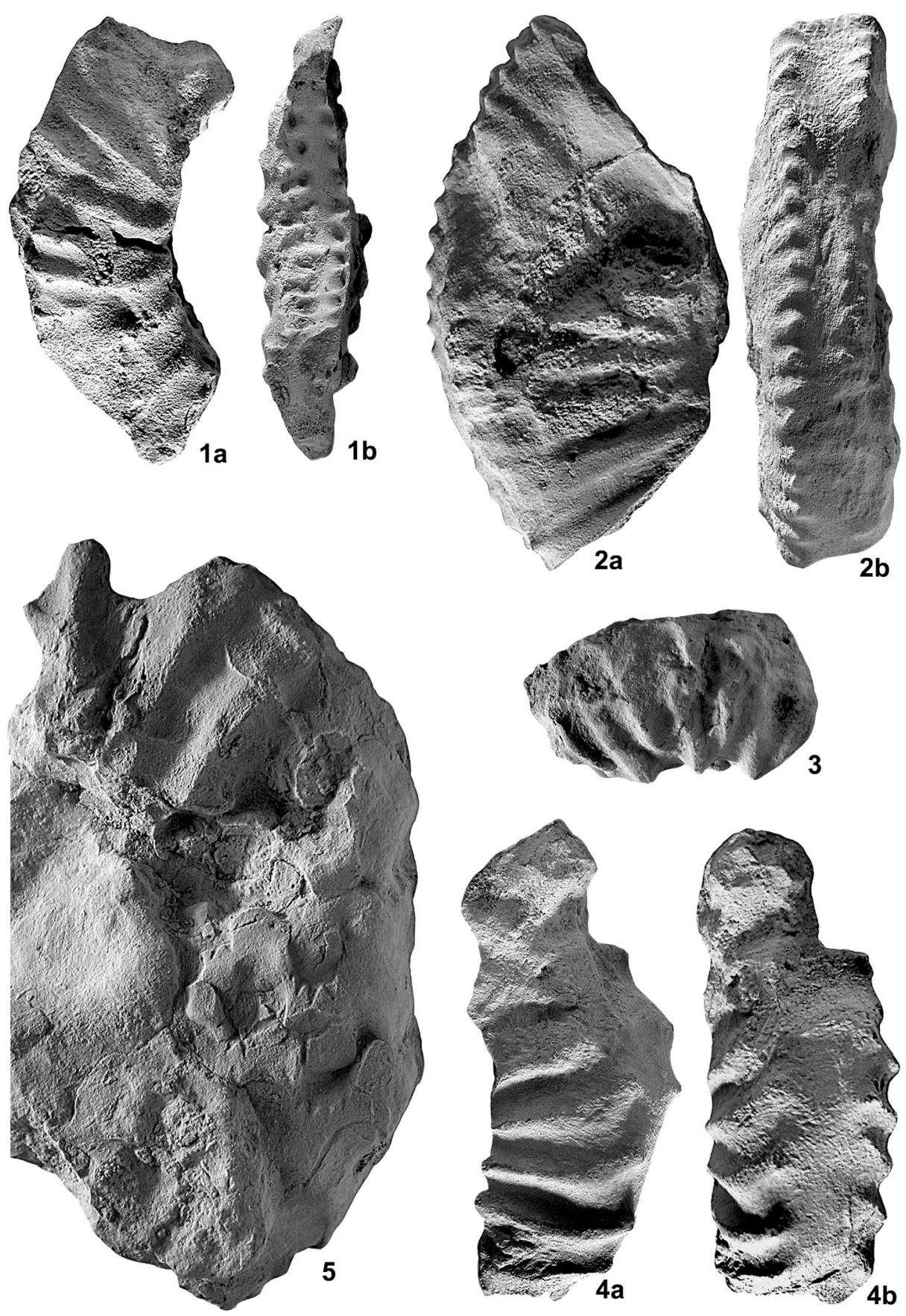

Central European Geology 51, 2008 
curionii (Mojsisovics 1882) Plate I, Fig. 5) and Falsanolcites cf. rieberi (Fantini Sestini 1994) (Plate II, Fig. 1).

In the end we can conclude that the clayey Bed 129/A is, both in lithology and in faunal content, the true equivalent of the "Chiesense groove" (at Bagolino, Pertica, M. Corona, etc. in Giudicarie: Brack and Rieber 1986, 1993), and the overlying Bed 129 already belongs to the Curionii Zone. This means that the base of the Ladinian (according to the recent decision by the ICS) can be pinpointed in the Felsőorrs section at the base of Bed 129. This level almost coincides with an important conodont datum, the FAD of the "G. bakalovi group" that was recorded by Kovács (1994) in bed "10/86" (equivalent to our Bed 130).

\section{Improved correlation with the Global Stratotype Section (Bagolino)}

The Global Stratotype Section (GSS) of the Ladinian Stage at Bagolino lies in the Giudicarie area (Southern Alps, Italy). In the Giudicarie, the critical Anisian-Ladinian stratigraphic interval ("Zone des Trachyceras Reitzi und des Trachyc. Curionii"; Mojsisovics 1880, p. 717) was recognized and described somewhat later (Mojsisovics 1880; Bittner 1881) than in the Balaton area (Felsőörs, Böckh 1872, 1873). The first proper comparison and correlation of the two ammonoid faunas were given by Mojsisovics (1882). The need for up-to-date comparisons and the re-evaluation of the stratigraphic correlation between the ammonoid faunas and sections of the Giudicarie and Balaton areas appeared in recent articles (Brack and Rieber 1986, 1993; Kovács et al. 1990; Mietto and Manfrin 1995). Stimulated by the discussions on the Anisian/Ladinian boundary, the main points of the detailed biostratigraphic correlation between the representative sections of the two areas have been outlined (Brack and Rieber 1994; Vörös et al. 1996). It was agreed that short-ranging ammonoid taxa provided excellent correlation of the South Alpine and Balaton sections. The detailed correlation scheme of Bagolino and Felsőörs, the two GSSP candidate

$\leftarrow$ Plate I

All specimens are in natural size and are deposited in the Department of Paleontology and Geology, Hungarian Natural History Museum, under the inventory numbers prefixed by $\mathrm{M}$.

1. Nevadites cf. avenonensis Brack and Rieber, 1993 - M 2009.340.1., Felsőörs, Bed 126, Secedensis Zone; a: lateral view, b: dorsal view: inner surface of the body chamber.

2. Chieseiceras chiesense (Mojsisovics, 1882) - M 2009.341.1., Felsőörs, Bed 129/A, Secedensis Zone; a: lateral view, b: ventral view.

3. Nevadites cf. avenonensis Brack and Rieber, 1993 - M 2009.342.1., Felsőörs, Bed 126, Secedensis Zone; oblique ventrolateral view.

4. Nevadites cf. avenonensis Brack and Rieber, 1993 - M 2009.343.1., Felsőörs, Bed 126, Secedensis Zone; a: lateral view, b: ventral view.

5. Eoprotrachyceras cf. curionii (Mojsisovics, 1882) - M 2009.344.1., Felsőörs, Bed 129, Curionii Zone; lateral view, showing part of the suture line. 
332 A. Vörös et al.

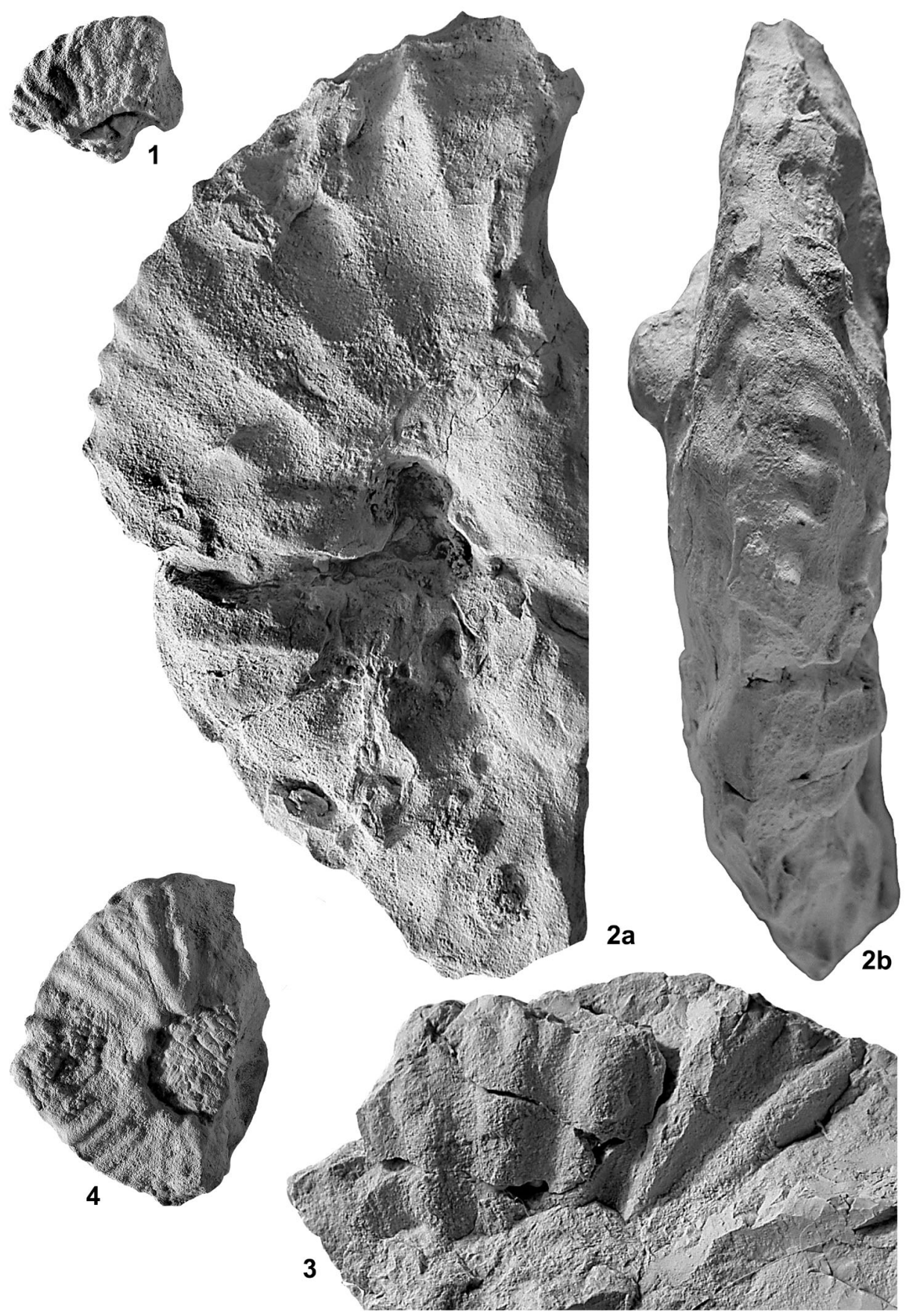

Central European Geology 51, 2008 
sections, was spectacularly illustrated by Brack et al. (2005, fig. 8$)$. It was seen that the perfect correlation was restricted to the lower part of the extended Anisian/Ladinian boundary interval, from the uppermost part of the Trinodosus Zone, through the Reitzi Zone to the lower part of the Secedensis Zone. The missing or insufficient record of the upper Secedensis and the Curionii Zones at Felsőörs was probably one of the reasons for its defeat by Bagolino during the voting.

The results of our new excavations and sampling significantly completed the ammonoid record of the Felsőörs section. This allows us to outline an improved correlation between the Bagolino and Felsőors sections, as shown in Fig. 4. The Bagolino column was applied from Brack et al. (2003, fig. 7b) with slight modifications; the ammonoid record was complemented with the items for Halilucites rusticus and Aplococeras avisianum after the subsequent findings by Mietto et al. (2003b). The Felsöörs column was taken, slightly modified from, Vörös et al. (2003, fig. 5), complemented with the recently exposed upper part and the new ammonoids. Generally we followed the style and the principal features of the correlation scheme published by Brack et al. (2005, fig. 8), except for the procedure of elimination of tuffaceous intervals from the Felsöörs column. This speculative action brings closer the thickness proportions of the Bagolino and Felsőörs sections but obscures reality: tuffite is a sedimentary rock and is an integral part of the sedimentary column. Therefore, in our Fig. 4, the Felsőorrs column is shown in actual thickness. In the biozonal scheme (right column) we evidently abandoned the transient view of our "proposal" (Vörös et al. 2003) and turned back to the traditional concept of the Reitzi Zone with four subzones (Márton et al. 1997; Vörös 1998; Pálfy et al. 2003). The Secedensis and Curionii Zones are used in accordance with Brack et al. (2005). At present nine more or less properly correlated faunal horizons can be recognized between the GSS (Bagolino) and Felsőörs (Fig. 4).

The lowermost level of correlation is based on the occurrences of Asseretoceras and Lardaroceras species. The representatives of these were collected in great number from the uppermost gray limestone beds of the Felsőörs Formation in the Felsőörs section (Beds 99-99/C). It should be mentioned that these ammonoids do

$\leftarrow$ Plate II

All specimens are in natural size and are deposited in the Department of Paleontology and Geology, Hungarian Natural History Museum, under the inventory numbers prefixed by M.

1. Falsanolcites cf. rieberi Fantini Sestini, 1994 - M 2009.345.1., Felsőörs, Bed 129, Curionii Zone; lateral view.

2. Chieseiceras chiesense (Mojsisovics, 1882) - M 2009.346.1., Felsőörs, Bed 129/A, Secedensis Zone; a: lateral view, b: ventral view.

3. Chieseiceras chiesense (Mojsisovics, 1882) - M 2009.348.1., Felsőörs, Bed 129/A, Secedensis Zone; lateral view.

4. Chieseiceras sp. - M 2009.347.1., Felsőörs, Bed 126, Secedensis Zone; lateral view. 


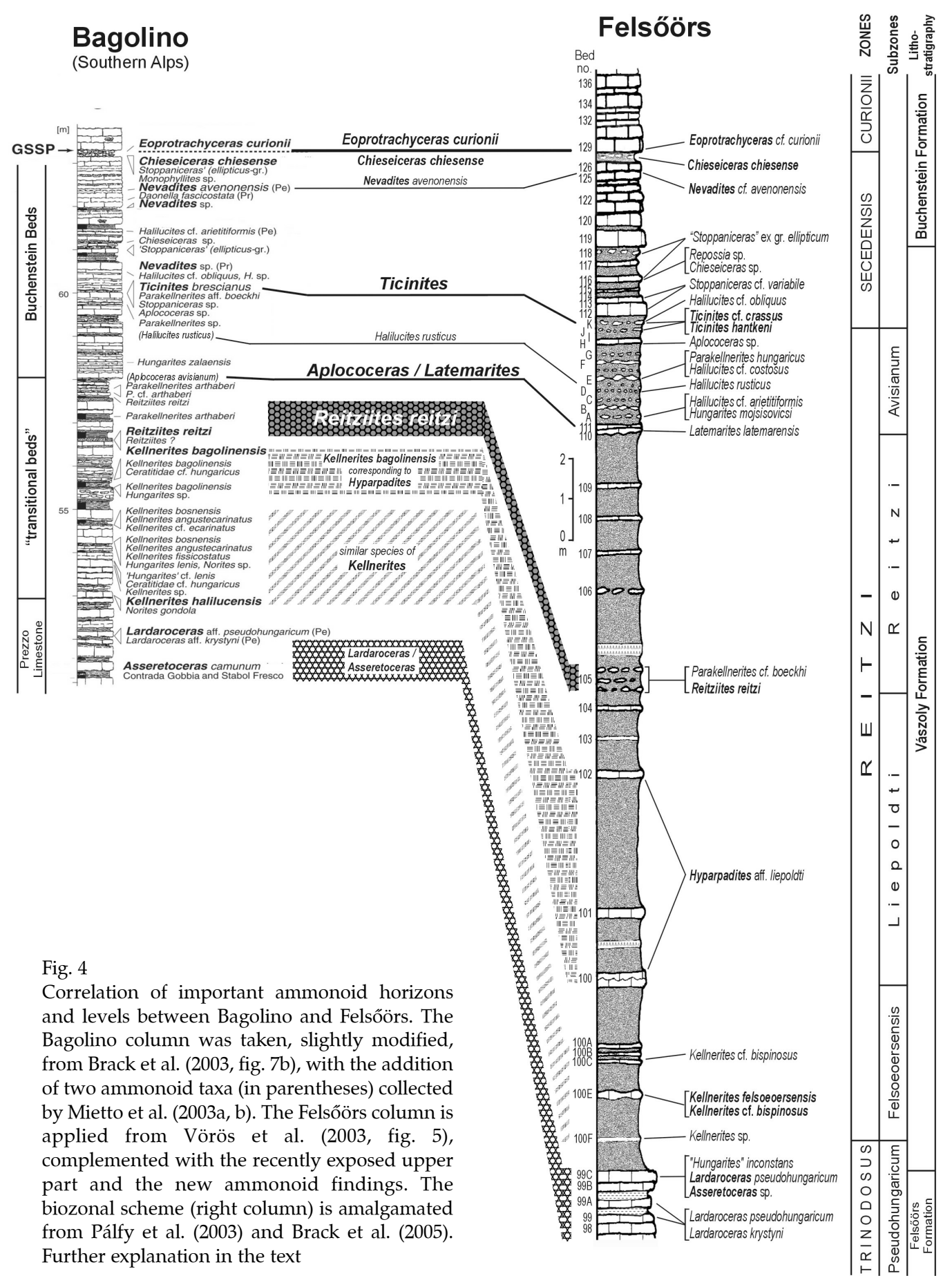


not occur in Bagolino: Lardaroceras was found in Pèrtica (ten $\mathrm{km}$ south of Bagolino), Asseretoceras is frequent at Contrada Gobbia and Stabol Fresco (more than twenty km northward from Bagolino; see Balini 1992).

The appearance of various Kellnerites species provides the correlation tool for the next interval. Kellnerites felsoeoersensis and bispinosus were found in Beds 100/C-E in Felsőörs, whereas K. halilucensis, fissicostatus, bosnensis, angustecarinatus and ecarinatus were reported from the 53 to $55 \mathrm{~m}$-interval of the Bagolino section. Obviously we have too many names; some of them would be synonymized under the senior name felsoeoersensis, others probably would belong to some different genus. Nevertheless, the genus Kellnerites itself offers a sound base of correlation and is the index of the Felsoeoersensis Subzone (Vörös et al. 1996).

The next interval was correlated on the basis of some curious (Para)Kellneriteslike ammonoid species with two lateral rows of nodes. They were described as Arpadites liepoldti (Mojsisovics, 1882) from Felsöörs, where they were recently collected from Beds 100 to 102. Forms with basically similar ornamentation, but belonging to different species, were described by Brack and Rieber (1993) as Kellnerites bagolinensis from the 55.5 to $56.6 \mathrm{~m}$-interval of the Bagolino section. The above species should probably be included to the genus Hyparpadites Spath, 1951, the diagnostic genus of the Liepoldti Subzone (Vörös et al. 1996).

Perhaps the best marker horizon, correlated between Bagolino and Felsőörs, is provided by Reitziites reitzi. This celebrated ammonoid was described and profusely illustrated from Felsőörs (Böckh, 1872, 1873; Stürzenbaum, 1875; Mojsisovics, 1882) but our recent samplings showed that it is restricted to a rather narrow, less than one meter-thick interval, to the flaser bedded and nodular layers merged as Bed 105. Surprisingly, Reitziites reitzi has an even better record in Bagolino; numerous specimens were collected from a one meter interval (56.6 to $57.6 \mathrm{~m}$ ) and, as is seen from the splendid illustration by Brack and Rieber (1993), even the state of preservation is a bit better than in Felsőors. (Alas, this excellent correlation horizon did not deserve the "golden spike"!)

Somewhat less firmly evidenced is the next level of correlation between Bed 110 of Felsőörs and a bed at $57.8 \mathrm{~m}$ of the Bagolino section that would mark the base of the Avisianum Subzone (Vörös et al. 1996, 2003). The concurrent appearance of different species of Aplococeras and Latemarites is a basic character of this subzone (Vörös et al. 1996; Manfrin et al. 2005). Although the presence of the Avisianum Subzone as an "Oppel-zone" is well-established in Felsöörs (mainly on the basis of Parakellnerites and Halilucites species), the record of the above diagnostic genera is poor and ambiguous. Decades ago, two specimens of Latemarites latemarensis were found there by L. Krystyn and were donated to us. On the basis of their matrix, the specimens probably derived from Beds 110 or 111, but no further Latemarites specimens came about during our subsequent samplings. A single Aplococeras sp. was found a little higher, in Bed 111/H. The sporadic occurrence of Latemarites and Aplococeras in the basinal facies in Felsőörs is environmentally controlled: both genera reached definite abundance in peri- 
platform settings in the Balaton area (Vörös 2002), and, though Mietto et al. (2003) argued otherwise, it seems to be fundamentally true in the Southern Alps as well. Accordingly, the basinal Bagolino section is devoid of Latemarites, and the record of Aplococeras was also very poor, until Mietto et al. (2003b) collected several specimens, permitting the identification of different species (A. avisianum, $A$. aff. smithi).

The next level of correlation between Bagolino and Felsőörs, suggested by Brack et al. (2005), is based on the mutual occurrence of Halilucites rusticus. This species was found in Bed 111/D in Felsőörs (Vörös et al. 2003), whereas in the Bagolino section it was collected by Mietto et al. $(2003 \mathrm{a}, \mathrm{b})$ at about $59.2 \mathrm{~m}$. The importance of this level depends on the definition of the base of the Secedensis Zone. Mietto et al. (2003b) suggested shifting down the base of their Crassus Subzone (the actual equivalent of the Secedensis Zone) to this horizon. On the other hand, we agree with Brack et al. $(2003,2005)$ in defining the base of the Secedensis Zone with the first appearance of Ticinites. Consequently, the level with Halilucites rusticus is of secondary importance, because it falls within the range of the Avisianum Subzone, but underlines the accuracy of the correlation.

One of the best correlated horizons is marked by the appearance of the genus Ticinites, represented by partly different species in both sections. T. hantkeni and T. cf. crassus were collected from Beds 111/J and 111/K in Felsőörs; T. brescianus was indicated by Brack and Rieber (1993) from the $60-\mathrm{m}$ point of the Bagolino section. Further species of Ticinites were described from different South Alpine sections (T. polymorphus from M. San Giorgio, T. dolomiticus from Seceda). Here again, it seems that we have too many names and some of the above species may prove to be junior synonyms of T. hantkeni or T. crassus. Nevertheless, it is well seen that the FAD of the genus Ticinites in itself is an excellent marker of the base of the Secedensis Zone and helps to overcome the drawback arisen from the debated taxonomy and rare occurrence of Nevadites in the Alpine sections.

The recently exposed and sampled part of the Felsőorrs section offered further potential levels of correlation with the Bagolino section. One of these is based on the occurrence of Nevadites avenonensis. This correlation bears some ambiguity, because the specimens collected from Bed 126 in Felsőörs (Plate I, Figs 1, 3, 4) are rather poorly preserved, and because $N$. avenonensis was described from the surroundings of Pèrtica and its level was only extrapolated to the $62.4-\mathrm{m}$ point of the Bagolino section.

The uppermost good correlation horizon between Felsőörs and Bagolino (and some other sections in Giudicarie), i.e. the base of the Curionii Zone, rests on a complex of evidence. Firstly, there is a remarkable lithological feature, the "Chiesense Groove", a dm-thick clayey interlayer with limestone nodules in the rather monotonous limestone bed sequences of the above-mentioned sections (Brack and Rieber 1986, 1993; Brack et al. 2005). In Bagolino and the auxiliary sections the ammonoid fauna of this layer is dominated by Chieseiceras chiesense, a diagnostic, large species, the range of which is usually restricted to the "groove". 
The limestone bed immediately above the "Chiesense Groove" regularly yields the earliest species of Eoprotrachyceras (E. curionii), and in the same bed, or somewhat higher, the representatives of Falsanolcites appear (Brack and Rieber 1993; Brack et al. 2005). Our new samplings revealed almost perfectly analogous conditions, and by this the base of the Ladinian Stage, as recently ratified, is now proved in the Felsöörs section at Bed 129. It is worth mentioning that the "Chiesense groove" was interpreted by Mietto et al. (2003a) as corresponding to a maximum flooding surface, which was considered a serious drawback for a potential GSSP. Although we agree with this statement, we believe that this wellrecognizable horizon is an excellent tool for a short distance (Bagolino-Felsőörs) correlation.

Finally, it can be stated that the ammonoid biostratigraphic subdivision of the Felsőorss section is comparable to that of Bagolino, the Global Stratotype Section of the Ladinian Stage, and the correlation between them is exceptionally good. Felsőörs is considered the best international reference section for the Anisian to Ladinian boundary interval.

\section{Acknowledgements}

The authors are indebted to Drs. J. Haas and S. Kovács for critically reviewing the manuscript. The ammonoid photographs were taken by E. Hankó; part of the computer graphic work was done by A. Pentelényi; their effort is gratefully acknowledged. The research was supported by the Hungarian Scientific Research fund (OTKA Grant K 72633)

\section{References}

Balini, M. 1992: New genera of Anisian ammonoids from the Prezzo Limestone (Southern Alps). Atti Ticinensi di Scienze della Terra, 35, pp. 179-198.

Bittner, A. 1881: Ueber die geologischen Aufnahmen in Judicarien und Val Sabbia. - Jahrbuch der kaiserlich-königlichen geologischen Reichsanstalt, 31, pp. 219-370.

Bittner, A. 1892: Was ist norisch? - Jahrbuch der kaiserlich-königlichen geologischen Reichsanstalt, 42/3, pp. 387-396.

Böckh J. 1872: A Bakony déli részének földtani viszonyai. I (The geology of the southern part of the Bakony). - Magyar Kir. Földt. Int. Évk., 2/2, pp. 31-166. (In Hungarian.)

Böckh, J. 1873: Die geologischen Verhältnisse des südlichen Theiles des Bakony, I. - Mittheilungen aus dem Jahrbuche der königlichen ungarischen geologischen Anstalt, 2/2, pp. 27-182.

Böckh, J. 1874: Die geologischen Verhältnisse des südlichen Theiles des Bakony, II. - Mittheilungen aus dem Jahrbuche der königlichen ungarischen geologischen Anstalt, 3/1, pp. 1-180.

Brack, P., H. Rieber 1986: Stratigraphy and ammonoids of the lower Buchenstein beds of the Brescian Prealps and Giudicarie and their significance for the Anisian/Ladinian boundary. Eclogae Geologicae Helvetiae, 79/1, pp. 181-225.

Brack, P., H. Rieber 1993: Towards a better definition of the Anisian/Ladinian boundary: New biostratigraphic data and correlations of boundary sections from the Southern Alps. - Eclogae Geologicae Helvetiae, 86, pp. 415-527.

Brack, P., H. Rieber 1994: The Anisian/Ladinian boundary: retrospective and new constraints. Albertiana, 13, pp. 25-36. 
Brack, P., H. Rieber, A. Nicora 2003: The Global Stratigraphic Section and Point (GSSP) of the base of the Ladinian Stage (Middle Triassic). A proposal for the GSSP at the base of the Curionii Zone in the Bagolino section (Southern Alps, Northern Italy). - Albertiana, 28, pp. 13-25.

Brack, P., H. Rieber, A. Nicora, R. Mundil. 2005: The Global boundary Stratigraphic Section and Poin (GSSP) of the Ladinian Stage (Middle Triassic) at Bagolino (Southern Alps, Northern Italy) and its implications for the Triassic time scale. - Episodes, 28/4, pp. 233-244.

Budai, T., J. Haas 1997: Triassic sequence stratigraphy of the Balaton Highland, Hungary. - Acta Geologica Hungarica, 40/3, pp. 307-335.

Budai, T, G. Császár, G. Csillag, A. Dudko, L. Koloszár, Gy. Majoros 1999: A Balaton-felvidék földtana. Magyarázó a Balaton-felvidék földtani térképéhez, 1:50 000 (Geology of the Balaton Highland. Explanation to the Geological Map of the Balaton Highland, 1:50 000). - Occasional Papers of the Geological Institute of Hungary, 197, pp. 257 p.

Budai, T, G. Csillag, A. Vörös, L. Dosztály 2001: Középsô- és késő-triász platform- és medencefáciesek a Veszprémi-fennsíkon (Middle to Late Triassic platform and basin facies of the Veszprém Plateau [Transdanubian Range, Hungary]). - Bull. Hung. Geol. Soc., 131/1-2, pp. $37-70$.

Cros, P., I. Szabó 1984: Comparison of the Triassic volcanogenic formations in Hungary and in the Alps. Paleogeographic criteria. - Acta Geologica Hungarica, 27/3-4, pp. 265-276.

Haas, J., I. Szabó, A. Oraveczné Scheffer, Gy. Lelkes, S. Kovács, H. Kozur, J. Ivancsics 1986 Balatonfelvidék, Felsőörs, Forráshegy. - Magyarország geológiai alapszelvényei (Geological Key-sections of Hungary), MÁFI, Budapest, 5 p. (In Hungarian.)

Kovács, S. 1994: Conodonts of stratigraphical importance from the Anisian/Ladinian boundary interval of the Balaton Highland, Hungary. - Rivista Italiana di Paleontologia e Stratigrafia, 99/4, pp. 473-514.

Kovács, S., A. Nicora, I. Szabó, M. Balini 1990: Conodont biostratigraphy of Anisian/Ladinian boundary sections in the Balaton Upland (Hungary) and in the Southern Alps (Italy). - Courier Forschungs Institut Senckenberg, 118, pp. 171-195.

Kovács, S., L. Dosztály, F. Góczán, A. Oravecz-Scheffer, T. Budai 1994: The Anisian/Ladinian boundary in the Balaton Highland, Hungary. - A complex microbiostratigraphic approach. Albertiana, 14, pp. 53-64.

Manfrin, S., P. Mietto, N. Preto 2005: Ammonoid biostratigraphy of the Middle Triassic Latemar platform (Dolomites, Italy) and its correlation with Nevada and Canada. - Geobios, 38, pp. 477-504.

Márton, E., T. Budai, J. Haas, S. Kovács, I., Szabó, A. Vörös 1997: Magnetostratigraphy and biostratigraphy of the Anisian-Ladinian boundary section Felsőörs (Balaton Highland, Hungary). - Albertiana, 20, pp. 50-57.

Mietto, P., S. Manfrin 1995: A high resolution Middle Triassic ammonoid standard scale in the Tethys Realm. A preliminary report. - Bulletin de la Société Géologique de la France, 1995/5, pp. 539-563.

Mietto, P., S. Manfrin, N. Preto, P. Gianolla, L. Krystyn, L., G. Roghi 2003a: The Global Stratigraphic Section and Point (GSSP) of the base of the Ladinian Stage (Middle Triassic). A proposal for the GSSP at the base of the Avisianum Subzone (FAD of Aplococeras avisianum) in the Bagolino section (Southern Alps, NE Italy). - Albertiana, 28, pp. 26-34.

Mietto, P., P. Gianolla, S. Manfrin, N. Preto 2003b: Refined ammonoid biochronostratigraphy of the Bagolino section (Lombardian Alps, Italy), GSSP candidate for the base of the Ladinian Stage. Rivista Italiana di Paleontologia e Stratigrafia, 109/3, pp. 449-462.

Mojsisovics, E. 1880: Ueber heteropische Verhältnisse in Triasgebiete der lombardischen Alpen. Jahrbuch der kaiserlich-königlichen geologischen Reichsanstalt, 30, pp. 695-718.

Mojsisovics, E. 1882: Die Cephalopoden der mediterranen Triasprovinz. - Abhandlungen der kaiserlich-königlichen geologischen Reichsanstalt, 10, pp. 1-322. 
Pálfy, J., R.R. Parrish, K. David, A. Vörös 2003: Middle Triassic integrated U-Pb geochronology and ammonoid biochronology from the Balaton Highland (Hungary). - Journal of the Geological Society (London), 160/2, pp. 271-284.

Roth, L. 1871: A Felső-Örs melletti Forráshegy lejtőjének geológiai átmetszete (The geological crosssection of the slope of Forráshegy at Felső-Örs). - Földtani Közlöny, 1/9, pp. 209-215. (In Hungarian.)

Stürzenbaum, J. 1875: Adatok a Bakony Ceratites Reitzi-szint faunájának ismeretéhez (Data to the knowledge of the fauna of the Ceratites Reitzi-horizon of the Bakony). - Földtani Közlöny, 5/11-12, pp. 253-262. (In Hungarian.)

Szabó, I., Cs. Ravasz 1970: Investigation of the Middle Triassic volcanics of the Transdanubian Central Mountains, Hungary. - Annales Historico-naturales Musei Nationalis Hungarici, 62, pp. 31-51.

Szabó, I., S. Kovács, G. Lelkes, A. Oravecz-Scheffer 1980: Stratigraphic investigation of a Pelsonian-Fassanian section at Felsőörs (Balaton Highland, Hungary). - Rivista Italiana di Paleontologia e Stratigrafia, 85, pp. 789-806.

Vörös, A. 1993: Redefinition of the Reitzi Zone at its type region (Balaton area, Hungary) as the basal zone of the Ladinian. - Acta Geologica Hungarica, 36/1, pp. 15-38.

Vörös, A. 1998: A Balaton-felvidék triász ammonoideái és biosztratigráfiája (Triassic ammonoids and biostratigraphy of the Balaton Highland). - Studia Naturalia, 12, pp. 105 p. (In Hungarian.)

Vörös, A. 2002: Paleoenvironmental distribution of some Middle Triassic ammonoid genera in the Balaton Highland (Hungary). - Abhandlungen der geologischen Bundesanstalt, 57, pp. $479-490$.

Vörös, A., T. Budai, J. Haas, S. Kovács, H. Kozur, J. Pálfy 2003: GSSP (Global Boundary Stratotype Section and Point) proposal for the base of Ladinian (Triassic). A proposal for the GSSP at the base of the Reitzi Zone (sensu stricto) at Bed 105 in the Felsöörs section, Balaton Higland, Hungary. - Albertiana, 28, pp. 35-47.

Vörös, A., I. Szabó, S. Kovács, L. Dosztály, T. Budai 1996: The Felsöörs section: A possible stratotype for the base of the Ladinian stage. - Albertiana, 17, pp. 25-40. 